\title{
Voksenhet som en måte å prøve å være hjemme på i verden - en oppgave for pedagogikk i kunstfagene
}

\section{Anna-Lena Østern}

NTNU, Norges teknisk-naturvitenskaplige universitet

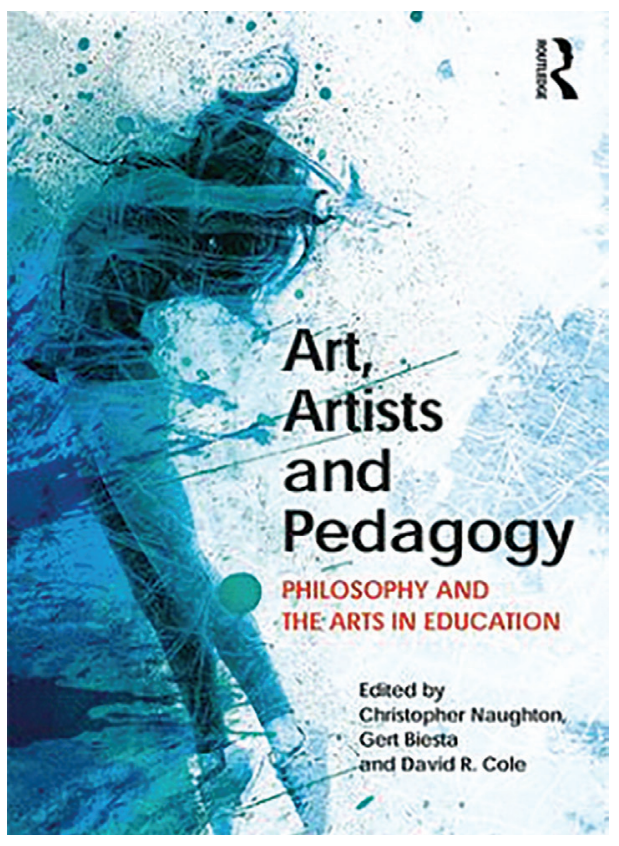

Christopher Naughton, Gert Biesta and David Cole (Eds.). (2018). Art, Artists and Pedagogy. Philosophy and the Arts in Educa-tion. Routledge. 160 sider.

Boken Art, Artists and Pedagogy er en bok som løfter frem filosofiske perspektiver på kunst i utdanning. Det er en bok dominert av Gert Biestas pedagogiske filosofi, men i dialog med Deleuze og Guattaris immanensfilosofi. Tungt å lese? Ja, men tekstene åpner seg hvis man gir dem tid. Biestas kraftfulle innledningskapittel er et anslag som klinger gjennom bokens alle 15 kapitler.

Boken har tre redaktører: Christoffer Naughton fra University of Auckland, Gert Biesta fra Brunel University London og David R. Cole fra Western University of Sydney. Cole har valgt å skrive og forske med især Deleuzes filosofi som inspirator 


\section{A.-L. Østern}

for sin skriving. Cole undersøker hvordan Deleuze og Guattaris filosofi kan fungere som kritikk av utdanningspraksis, men også som vitalisering og forandring av utdanning. Bokens ambisjon er tydelig fremskrevet i dedikasjonen: «A book dedicated to all those who teach the arts, and who wish to embrace nature, art and the politics of change».

Biestas kapittel «What if? Art education beyond expression and creativity» er bokens sentrale tekst. I innledningen til kapittelet gjør Biesta et tankeeksperiment gjennom å forestille seg hva historikere om hundre år vil si om vår tid, som han beskriver som besatt av målbare resultater. Han mener at global utdanning da har kommet til sans og samling og innsett at global utdanning har blitt et ikke-bærekraftig monster, som gjør det motsatte av hva utdanning skulle gjøre: å tjene menneskeligheten i streben etter fredelig sameksistens innenfor rammene av det jorden kan tilby.

Videre beskriver Biesta sin pedagogiske filosofi gjennom å tegne to trusselbilder: Kunsten forsvinner bort fra kunstpedagogikken og pedagogikken bort fra kunstfagene. Det første bildet er den bevegelse vi ser i dag med marginalisering av kunstfagene i skole og utdanning. Motiveringen for kunstfagene er instrumentell - det som betyr noe er hva kunstfagene bidrar til i andre fag eller områder. Biesta argumenterer også mot tanken om kunst for kunstens skyld. Og her er det to misforståelser som han påtaler: at barn og unge må få uttrykke seg og sin stemme uten grenser, og at alt kan kalles kreativitet. Å uttrykke seg kan gjøres på gode og dårlige måter. Kreativitet kan brukes på gode og destruktive måter. Her kommer Biestas hovedpoeng: Hvis pedagogikken forsvinner fra kunsten i utdanning; er det som da potensielt skjer, ønskelig? Biesta er opptatt av hva utdanning betyr, og han formulerer seg med støtte i Hannah Arendts tanker om hva det betyr å eksistere som et subjekt på en voksen måte i verden gjennom motstand og dialog.

\section{Å eksistere på en voksen måte på en plass i midten}

Det som kunstfagene kan bidra til, er å la unge mennesker forholde seg til hva det betyr å uttrykke seg selv og sine drømmer, men i dialog med «den andre» - å spørre seg om det jeg som individ ønsker og drømmer er ønskelig også for de andre og kloden vår. Dette blir en viktig oppgave for utdanning, og her er både motstand og dia-log nødvendig. Biesta. beskriver kraften i kunst i pedagogisk arbeid på følgende mån makes oup desires visible, gives them form, and by trying to come into dialogue

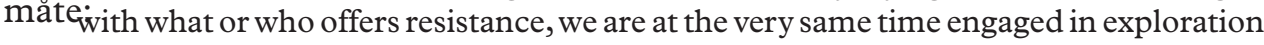
of the desirability of our desires and in their rearrangement and transformation.

(Biesta, 2018, s. 18)

Biesta beskriver undervisning som å forstyrre drømmer og ønsker for å finne ut av hvilke som hjelper oss å leve i og med verden på voksne måter.

Biesta sammenfatter sine poenger gjennom å peke på «the middle ground", en plass mellom selvdestruksjon og verdensdestruksjon, som en dialogisk plass hvor utdanning kan ta seg av oppgaven å fostre voksne måter å være i dialog med verden på - og 
her, tenker Biesta, kan kunst tilby unike muligheter for å arbeide med den oppgaven, hvis kunsten får en tilstrekkelig stor plass i skole og utdanning.

I kapitlene som følger etter Biestas tanker om kunstfagenes bidrag i skole og utdanning, følger interessante bidrag fra andre perspektiver. Især begreper fra Deleuze og Guattari har inspirert mange av de andre forfatterne i deres filosofiske drøftinger av begreper som rhizom, persept, affekt, begrep og territorialisering. Kapitlene er alle knyttet til kunstfaglig arbeid eller kunstnerisk uttrykk. Noen eksempler er David Lines tekst om free jazz, Nico de Vos' tekst om "connectedness in motion», i dans, samt Jessie Beier og Jason Wallins tekst om film med Deleuze som inspirator.

Disse tekstene kjemper med å bruke Deleuze og Guattaris filosofiske tenkning i undersøkelse av konkrete praksiser. I høy grad lykkes de med å gjennomføre filosofiske analyser som kommuniserer med leseren. Alle knytter an til Biestas tenkning, eller prøver i hvert fall å gjøre det.

I boken har Biesta intervjuet John Baldacchino (fra University of Wisconsin Madison) om "to unlearn», som i Baldacchinos forståelse betyr å ikke holde fast ved kanon, det man har lært før, men å forholde seg til sin egen virkelighet og forme sin forståelse utfra den.

Bokens siste kapittel er også skrevet av Biesta, og han forholder seg her forsiktig til de andre forfatternes tekster, men konkluderer med å løfte fram betydningen av undervisning og av læreren.

Som en konklusjon vil jeg løfte fram en setning fra innledningskapittelet. Naughton og Cole siterer Deleuze (1994, s. 45) om å gjenta: «(...) we die a little every day without the arts». De oppfordrer i bokens innledningskapittel leserne til å endre frykten for eksperimentering, det ukjente og risikable for å gjøre noe nytt som virkelig tar i bruk livskrefter i det lokale.

Det er en bok til å bli klok av og også til å inspireres av som utdanner, kunstner og forsker.

\section{Referanser}

Biesta, G. (2018). What if? Art Education beyond Expression and Creativity. I C. Naughton, G. Biesta \& D. R. Cole (Red.), Art, Artists and Pedagogy Philosophy and the Arts in Education (s. 11-20). London and New York: Routledge.

Deleuze, G., \& Guattari, F. (1987). A Thousand Plateaus: Capitalism and Schizophrenia (Oversatt av Brian Massumi). London: University of Minneapolis Press. 